\title{
Plackett-Burman Experimental Design for Investigating the Effect of Porcine Plasma Protein, Trehalose and Bovine Meat Protein Isolate on Cook Yield and Texture of Minced Bovine Meat
}

\author{
Vareltzis Patroklos ${ }^{1}$, Petridis Dimitris ${ }^{1}$, Argiro Petropoulou $^{1} \&$ Tsamitropoulou Fani ${ }^{1}$ \\ ${ }^{1}$ Department of Food Technology, ATEI of Thessaloniki, Thessaloniki, Greece \\ Correspondance: Vareltzis Patroklos, Department of Food Technology, ATEI of Thessaloniki, PO Box 141, \\ Thessaloniki 57400, Greece. Tel: 30-231-067-4779. E-mail: p.k.vareltzis@gmail.com
}

Received: April 18, 2013 Accepted: May 19, 2013 Online Published: May 27, 2013

doi:10.5539/jfr.v2n3p122 URL: http://dx.doi.org/10.5539/jfr.v2n3p122

\begin{abstract}
A common additive to counter the cooking losses considerations in the muscle food industry is sodium tripolyphosphate (STP), which however may pose health risk for certain segments of the population. This paper employs a Plackett-Burman design to investigate the effect of porcine plasma protein (PPP), protein isolate from bovine meat (PI), trehalose and $\mathrm{pH}$ of the additive mixture on cook yield and textural characteristics of minced beef during frozen storage. Results show that PI and PPP significantly $(\mathrm{p}<0.05)$ increase the cooking yield throughout the storage period compared to the control sample. Fresh samples with PPP, PI and STP had $\sim 90 \%$ cooking yield, while control sample had only $75 \%$. PI and PPP can improve the cooking yield of minced beef for the first two months of storage by at least $20 \%$, in a similar and comparable pattern with STP. Upon optimization the optimal values were achieved at PI concentration 2.3-5.0\% and PPP levels 1.7-4.7\%.
\end{abstract}

Keywords: porcine plasma protein, trehalose, Plackett-Burman, cook yield, STP, protein isolate

\section{Introduction}

\subsection{Cook Losses in the Meat Industry}

The major changes occurring in meat during cooking are shrinkage, toughening of tissues, releasing of meat juice and colour changes (Dreeling et al., 2000; Vittadini et al., 2005). These are caused by the changes in muscle proteins, e.g., denaturation of muscle proteins and shrinkage of collagen due to the increase in temperature. All these leads to changes in textural properties, decrease in the water-holding capacity of proteins, and hence cook losses, which are important economic considerations. Therefore, minimization of cook losses to a certain safety

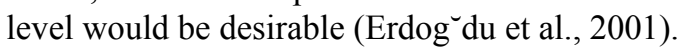

\subsection{Limitations of Polyphosphate Salts}

The meat processing industry uses phosphates to improve textural properties and to reduce cook losses. Action mechanism of phosphates, which exhibit a pronounced polyionic character, is based on the ionization of protein molecules, increasing the interaction between protein and water molecules due to increased $\mathrm{pH}$ and ionic strength, and reducing the interaction among the proteins (Cheftel et al., 1985; Martin et al., 2002; Unal et al., 2006). Sodium tripolyphosphates (STPs) are actually the most popular form of phosphates used in the meat industry (Dzeizak, 1990; Lampila, 1992). However, sodium tripolyphosphate is a suspected neurotoxin according to the National Institute for Occupational Safety and Health's (NIOSH) Registry of Toxic Effects of Chemical Substances. Several studies which focused on the effect of the addition of phosphates on consumer health have been published and these studies have given contradictory results. The kidneys easily control the blood phosphorus level and efficiently excrete any excess of phosphorus; hence, up to now, there is no evidence that higher phosphate intakes are detrimental to bone health or to bone calcium excretion in the urine in healthy adults not having problems with kidneys (Fenton et al., 2009; Whybro et al., 1998). However, in the study of Huttunen et al. (2006) with adult rats, excessive intake of dietary phosphate without the company of calcium caused rise in concentration of serum parathyroid hormone and hindered mineral deposition into cortical bone, leading to lower bone mineral density. High dietary phosphorus also has significant effects on cardiac fibrosis and arterial wall thickening, relevant for increased cardiac risk especially in haemodialysis and chronic kidney disease patients (Amann et al., 2003; Foley et al., 2009; Sherman \& Mehta, 2009). These controversies over 
human health, as well as increasing consumer concerns about additives in foodstuff justify the interest in replacing polyphosphates with natural ingredients.

\subsection{Previous Work on Substistution of Polyphosphate Salts}

Other ingredients can be introduced in meat products to obtain polyphosphate-free-products without losing yield or sensory quality. Several additives and non-meat ingredients have been used to enhance the water-binding capacity of cooked sausages. Atughonu et al. (1998) reported that sodium caseinate, soy protein isolate, whey protein concentrate, and wheat germ flour increased the cooking yield in frankfurters. Most of the ingredients that can help in binding water, stabilizing emulsions and increasing firmness of meat products are proteins. Egg, milk, soya and wheat proteins may pose health concerns because of potential allergenicity.

Blood plasma from slaughtered animals has been shown to be a good food ingredient due to its gelling properties as well as its ability to improve water holding capacity, and emulsion stability (Cofrades et al., 2000; Dàvila et al., 2007; Parés \& Ledward, 2001). Also, the use of blood proteins in the food industry is a good way to upgrade this by-product and hygienically collected blood is a raw material that is a cheap food ingredient which has not been shown to be allergenic. Moreover, since blood is naturally present in meat, the introduction of blood derivatives in meat products does not involve the addition of an unnatural ingredient.

Protein isolates derived by a $\mathrm{pH}$-shift process have been shown to have improved functional characteristics (Tahergorabi et al., 2012a). Protein isolates, besides myosin and actin, are enriched in sarcoplasmic proteins. These proteins have been shown to improve textural characteristics of cooked sausages (Farouk et al., 2001). The $\mathrm{pH}$-shift method has been extensively applied to various fish-species and fish processing byproducts (Nolsoe \& Undeland, 2009). However, there is little literature data on protein isolates from other type of muscles such as chicken (Tahergorabi et al., 2011; Tahergorabi et al., 2012b), turkey (Liang \& Hultin, 2003) and especially beef muscle used as an enhancer in meat products.

To protect myofibrillar proteins from freeze-denaturation during frozen storage and to maintain its possible high processability, cryoprotectants, such as disaccharides, polysaccharides, polyalcohols or polyphosphates are generally added (Park et al., 1988; Mac Donald \& Lanier 1991). Trehalose (d-glucopyranosyl- $\alpha(1 \rightarrow 1)$-d-glucopyranoside) is a non-reducing disaccharide with a low calorific value and low sweetness, i.e. only $45 \%$ of that of sucrose (Colaco et al., 1994). Because of its ability to form strong hydrogen bonds with the polar group of biomolecules and a very high glass transition temperature, trehalose has superior preservation properties as compared to other sugars (Patist \& Zoerb, 2005). Kovacevic and Mastanjevic (2011) showed that trehalose has a better cryoprotective effect than maltose on washed and frozen beef meat. So far, no information regarding the effect of trehalose on comminuted beef meat has been reported.

\subsection{Aim of This Study}

This work aims to investigate the effect of a) porcine plasma protein (PPP), b) protein isolate from beef muscle $(\mathrm{PI}), \mathrm{c})$ trehalose and $\mathrm{d}$ ) the $\mathrm{pH}$ of the addition mixture on cook yield, water holding capacity and textural properties of fresh and frozen ground beef muscle and then compare them to the polyphosphates effect. Since, all the investigations using full factorial design are tedious and multivariate methods, which is a collection of statistical and mathematical techniques, has been proved to be an effective way for the desired purpose (Petridis et al., 2013; Murphy et al., 2004; Rincón et al., 2008; Pereira et al., 2011; Kim et al., 2013), a Plackett-Burman design was chosen for the experimental design and analysis. The selected response variables were water holding capacity, cook yield and texture parameters such as hardness, firmness, gumminess, chewiness, cohesiveness.

\section{Materials and Methods}

\subsection{Materials}

Lean beef muscle was purchased from local retail shop and was transferred to the laboratory in an ice box. All chemicals were of ACS grade and were obtained from Sigma-Aldrich SA.

\subsection{Sample Preparation}

Lean beef muscle tissue was trimmed from any visible fat and connective tissue and minced using a Kitchen Aid ultra power grinder (model KSM90, St. Joseph MI) through a $5 \mathrm{~mm}$ perforated plate. To all mince samples the following ingredients were added:
a. $\mathrm{NaCl} 2 \%(\mathrm{w} / \mathrm{w})$
b. Trehalose (TR): $0 \%$ or $3 \%(\mathrm{w} / \mathrm{w})$
c. Added distilled water: $10 \%(\mathrm{w} / \mathrm{w})$ 
d. Sodium Lactate $23.3 \%(\mathrm{w} / \mathrm{v})$ of the added distilled water

e. Protein isolate (PI): $1 \%$ or $5 \%(\mathrm{w} / \mathrm{v})$ calculated based on protein concentration of the added water

f. Porcine Plasma Protein (PPP): $1 \%$ or $5 \%(\mathrm{w} / \mathrm{v})$ of the added water

Sodium lactate, TR, PI, and PPP were mixed in the added water volume prior to the addition to the mince. The $\mathrm{pH}$ of the added solution was adjusted to 9 or 11 with $1 \mathrm{~N} \mathrm{NaOH}$.

Two more samples were prepared: the blank, which contained only $10 \%(\mathrm{v} / \mathrm{w})$ distilled water, $\mathrm{NaCl}$ and sodium lactate and the blank+STP sample, which additionally contained 3\% (w/v) STP in the added water.

The mince samples ( $30 \mathrm{~g})$ were packed in polyethylene cylindrical bags and either heated immediately in a water bath at $80^{\circ} \mathrm{C}$ to achieve an internal temperature of $72^{\circ} \mathrm{C}$ or placed in the freezer at $-20^{\circ} \mathrm{C}$ for 4 months. Each month, samples were taken out, thawed under cold running water and then cooked under the same conditions as the freshly prepared samples.

\subsubsection{Preparation of Porcine Plasma Protein (PPP)}

The procedure followed, was adapted from Benjakul et al. (2001). Porcine blood was collected from a slaughterhouse in Kalohori, Greece. Mean composition in \% (w/w) of the plasma was: moisture $90.2 \pm 0.004$, ash $1.66 \pm 0.01$, and protein $7.66 \pm 0.06$. Plasma was then freeze-dried and kept at $4^{\circ} \mathrm{C}$ until used. The dry powder was referred to as porcine plasma protein (PPP).

\subsubsection{Preparation of protein Isolate (PI)}

Proteins from lean beef meat were isolated by applying a pH-shift method (Vareltzis et al., 2008). Specifically, beef tissue was trimmed from any visible fat and connective tissue and minced using a KitchenAid ultra power grinder (model KSM90, St. Joseph MI) through a $5 \mathrm{~mm}$ perforated plate. Minced samples were transferred to a beaker and placed in a container filled with crushed ice and were homogenized in 9 volumes of cold distilled-deionized water for $40 \mathrm{~s}$ at $14000 \mathrm{rpm}$ using an Ultra Turrax T18 Basic homogenizer (IKA, Taquara, RJ, Brazil). The $\mathrm{pH}$ of the homogenate was brought to 10.8 (alkaline solubilization) with $2 \mathrm{~N} \mathrm{NaOH}$. The solubilized homogenate was filtered through three layers of commercial cheesecloth. The filtrate was readjusted to $\mathrm{pH} 5.3$ to precipitate the solubilized proteins, which were collected after filtration through 3 layers of cheesecloth.

The collected proteins, called protein isolate (PI), were analysed for moisture content and protein concentration by the Biuret method (Gornall et al., 1949). Mean composition of protein isolate was (w/w): moisture content $89.1 \pm 0.4 \%$, protein $10 \pm 0.2 \%$, fat $0.5 \pm 0.02 \%$ and ash $0.5 \pm 0.01 \%$.

\subsection{Experimental Design and Statistical Analysis}

A particular Plackett-Burman experimental design for screening significant effects on chemical and mechanical variables was chosen (Montgomery 2001). The design included 12 runs of two- leveled four factors (see Table 1 and sample preparation) and was repeated five times following the experimental freezing periods: $0,1,2,3,4$ months, with 0 freezing period representing the immediate cooking of the 12 samples that were prepared from fresh minced beef.

Table 1. Layout of the Plackett-Burman experimental design (uncoded values)

\begin{tabular}{lllll}
\hline Sample & $\mathrm{pH}$ of added solution & $\mathrm{PPP}(\% \mathrm{w} / \mathrm{v})$ & $\mathrm{TR}(\% \mathrm{w} / \mathrm{w})$ & $\mathrm{PI}(\% \mathrm{w} / \mathrm{v})$ \\
\hline 1 & 9 & 1 & 0 & 1 \\
2 & 9 & 5 & 0 & 5 \\
3 & 11 & 5 & 3 & 5 \\
4 & 11 & 5 & 0 & 1 \\
5 & 11 & 1 & 0 & 5 \\
6 & 9 & 1 & 3 & 1 \\
7 & 11 & 5 & 0 & 5 \\
8 & 11 & 1 & 3 & 1 \\
9 & 9 & 1 & 0 & 5 \\
10 & 11 & 1 & 3 & 5 \\
11 & 9 & 5 & 3 & 1 \\
12 & 9 & 5 & 3 & 1 \\
\hline
\end{tabular}


Analysis of variance was performed at different freezing times on the variables under study testing the potential effect of four factors, $\mathrm{pH}$ and three additives (PPP, PI, TR). Optimized combinations between additive levels of the most important attributes were attempted. The additives' effects were compared to those produced by polyphosphates and blank material by freezing month. The $95 \%$ confidence intervals of the means, produced from each Placket-Burman design, were used to compare with individual values of polyphosphate and blank material since the latter factors were not included in the experimental design. Means whose $95 \%$ intervals do not overlap denote pairwise statistically significant difference.

Finally, a Principal Component Analysis (PCA) was applied on the correlation matrix of attributes to detect the most important variables emerging at various additive combined levels at progressive freezing times.

All statistical designs and analysis were performed using the statistical software Minitab v.16 (Minitab Inc.).

\subsection{Measurements}

\subsubsection{Cook Yield (CY) and Water Holding Capacity (WHC)}

The mince samples $(30 \mathrm{~g})$ were placed in polyethylene cylindrical bags and heated in a water bath at $80^{\circ} \mathrm{C}$ to achieve an internal temperature of $72^{\circ} \mathrm{C}$. During cooking, the temperatures in the centre of the meat samples were monitored with a glass thermometer inserted in the centre of the sample. The drip was drained from the sample. The cooked mass was cooled and subsequently weighted to determine weight loss. Cook yield was determined as $100 \mathrm{x}$ (final weight/initial weight).

Water holding capacity was determined by centrifuging $2 \mathrm{~g}$ of cooked samples in the presenceof $\mathrm{Na}_{2} \mathrm{SO}_{4}$ at 3000 $\mathrm{x} \mathrm{g}$ for $10 \mathrm{~min}$ at room temperature. After blotting dry, the weight was recorded. WHC was calculated as 100x(initial weight/final weight) (Abdullah \& Al-Najdawi, 2005)

\subsubsection{Texture Analysis}

Experiments were performed using a TA-XT texture Analyzer (TA instruments, New Castle, DE), as described before by Ritzoulis et al. (2010). The analyzer was equipped with a 75 -mm-diameter aluminiumcylinder, operating with a compression rate of $5 \mathrm{~mm} / \mathrm{sec}$. Samples, $20 \mathrm{~mm}$ in length, were cut using a dedicated template ring, and axially compressed to $40 \%$ of their original height. The capacity of the load cell used was $30 \mathrm{~g}$. All tests were performed at least three times. TPA was performed 10 min aftecooking. The load cell was calibrated prior to use. TPA parameters were: hardness, cohesiveness, gumminess, chewiness.

The OriginPro 8.02 (OriginLab Corporation, USA) computer program was chosen to obtain graphic displays of the texture analysis data and perform the necessary calculations.

\subsubsection{Moisture Content, $\mathrm{pH}$ and our}

The moisture content was determined in triplicate by AOAC method 950.46 B (AOAC, 1990). The pHvalues of the samples were measured in duplicate (Thermo Orion 3STAR pH meter equipped with SN 9099083 electrode) on a homogenate of $1 \mathrm{~g}$ sample in $9 \mathrm{ml}$ distilled water.

The colour of the meat samples was measured using a HunterLab spectrocolourimeter (Hunter Lab Ltd., Reston, VA, USA) and expressed as CIE L*(lightness), $\mathrm{a}^{*}$ (redness) and $\mathrm{b}^{*}$ (yellowness) values.

\section{Results and Discussion}

\section{$3.1 \mathrm{pH}$ and Colour}

The $\mathrm{pH}$ of the samples varied between 5.8 and 6.2 (reported values are the mean of three readings) as it can be seen in Table 2. Even though the $\mathrm{pH}$ of the added solution was adjusted to two different values ( 9 and 11), there were only slight differences in the final $\mathrm{pH}$ of the samples before cooking (samples 1-12), probably due to the buffering capacity of the meat itself, as well as the added proteins. After cooking, the $\mathrm{pH}$ of all samples did not change significantly $(\mathrm{p}>0.05)$.

Certain treatments of minced beef exhibited significant effects $(p<0.05)$ on colour parameters when compared to the blank sample (Table 2). It is observed that samples 10,11 and 12 have significantly higher $L^{*}$ and $a^{*}$ values compared to the blank. These samples have 2 characteristics in common: high trehalose and high protein (either PPP or PI) content in the added solution. Since the protein source was either the blood plasma or the bovine meat, these differences can be attributed to residual haemoglobin/myoglobin. These observations suggest that porcine plasma and/or protein isolate can be used as replacers for artificial pigments. 
Table 2. Colour of fresh samples and $\mathrm{pH}$ before and after cooking (mean $\pm \mathrm{SD}, \mathrm{n}=3$ )

\begin{tabular}{llllll}
\hline Samples & $\mathrm{L}^{*}$ & $\mathrm{a}^{*}$ & $\mathrm{~b}^{*}$ & $\begin{array}{l}\mathrm{pH} \text { before } \\
\text { cooking }\end{array}$ & $\begin{array}{l}\mathrm{pH} \text { after } \\
\text { cooking }\end{array}$ \\
\hline blank & $28.5 \pm 0.98$ & $16.0 \pm 1.13$ & $8.0 \pm 2.5$ & 5.78 & 5.91 \\
Blank+STP & $26.9 \pm 3.18$ & $17.63 \pm 1.58$ & $9.3 \pm 1.60$ & 5.91 & 5.93 \\
1 & $38.5 \pm 2.76$ & $14.9 \pm 0.28$ & $5.5 \pm 0.20$ & 5.82 & 5.92 \\
2 & $28.5 \pm 0.57$ & $17.2 \pm 0.86$ & $8.7 \pm 0.21$ & 5.81 & 6.01 \\
3 & $23.3 \pm 2.37^{*}$ & $18.5 \pm 1.44$ & $7.9 \pm 0.69$ & 6.13 & 6.22 \\
4 & $27.8 \pm 2.76$ & $16.76 \pm 1.09$ & $9.1 \pm 0.26$ & 6.11 & 6.15 \\
5 & $29.8 \pm 0.65$ & $16.1 \pm 0.703$ & $9.4 \pm 0.58$ & 6.30 & 6.21 \\
6 & $25.3 \pm 0.65$ & $17.3 \pm 0.66$ & $8.3 \pm 0.69$ & 6.25 & 6.40 \\
7 & $24.9 \pm 2.6$ & $15.2 \pm 0.49$ & $8.4 \pm 1.87$ & 6.16 & 6.24 \\
8 & $27.7 \pm 3.3$ & $16.7 \pm 0.89$ & $6.9 \pm 1.03$ & 6.12 & 6.14 \\
9 & $33.1 \pm 4.45$ & $18.3 \pm 0.047$ & $9.5 \pm 1.60$ & 6.21 & 6.54 \\
10 & $30.8 \pm 1.20^{*}$ & $19.8 \pm 1.23^{*}$ & $10.6 \pm 0.84$ & 6.19 & 6.14 \\
11 & $32.1 \pm 0.81^{*}$ & $21.1 \pm 1.14^{*}$ & $10.5 \pm 0.87$ & 5.93 & 6.00 \\
12 & $33.9 \pm 1.81^{*}$ & $20.5 \pm 0.8^{*}$ & $11.3 \pm 0.82$ & 6.20 & 6.12 \\
\hline
\end{tabular}

*denotes significant difference from the blank $(\mathrm{p}<0.05)$.

\subsection{Significant Effects}

The Plackett-Burman's analysis of variance revealed significant effects of all additives on cook yield, moisture content, springiness and cohesiveness (Table 3). Specifically, Table 3 summarizes only the significant effects of the process variables (pH, PI, PPP and Trehalose (TR)) on the physicochemical parameters of the samples for every month of freezing (samples 1-12). Cook yield increased at 5\% PPP addition and in the two following freezing months. A similar pattern was observed for the other two factors considered (pH, PI). Porcine plasma protein has been shown to exhibit high hydrophilic character compared with dairy or meat proteins (Alting et al., 2002; Howell \& Lawrie, 1984; Zayas, 1985). PPP has been used to substitute STP and caseinate in frankfurters, where it was found that neither moisture nor WHC, as well as cooking losses showed significant differences (Hurtado et al., 2012). An increase in WHC had been observed by Cofrades et al. (2000) in meat products containing bovine plasma. The WHC increases with the concentrations of plasma protein only at concentrations lower than $8 \%$, while plasma proteins have a $\mathrm{pH}$ of around 7.3-7.5 that raises the meat $\mathrm{pH}$, leading to increased WHC (Chen \& Lin, 2002; Feiner, 2006).

In a similar manner, protein isolate from bovine muscle increased cook yield, achieving the highest value at the 5\% level of addition. Furthermore, protein isolate increased springiness and cohesiveness at low concentration levels (1\%). It has been shown that $\mathrm{pH}$ treatment of myofibrillar proteins significantly increased their solubility compared to native proteins. Good myofibrillar protein solubility is believed to be a prerequisite for many functional properties, including gelation and emulsification, and this is why salt is typically added to muscle-derived products to obtain desirable quality characteristics (Kristinsson \& Hultin, 2003). Furthermore, protein isolates are enriched in sarcoplasmic proteins. These proteins have been shown to improve textural characteristics of cooked sausages (Farouk et al., 2001). In addition, the fact that the $\mathrm{pH}$ of the solution was adjusted to 9 and 11 should further enhance the protein's ability to hold water and therefore minimize cook losses.

Trehalose decreased the moisture content when added at $3 \%$ for months 0 and 1 . On the contrary, trehalose increased springiness at the $3 \%$ level of addition for month 1 . These results can be explained by taking into account how trehalose stabilizes the proteins. According to the water replacement theory, which was presented to explain the unique properties of trehalose, the disaccharide is thought to substitute water around the proteins, maintaining their three-dimensional structure by providing sites with hydrogen-bonding species. This substitution also leads to a decrease in the solvation layer around the protein and restricts the mobility of the biological macromolecule (Jain \& Ipsita, 2009; Sola-Penn \& Meyer-Fernandes, 1998). Therefore, proteins actually bind less water, which then can be lost during cooking. 
Table 3. Statistically significant effects of additives on physicochemical and mechanical attributes of minced meat during freezing time. $95 \%$ confidence intervals of means based on pooled standard error and exact probability value are shown

\begin{tabular}{|c|c|c|c|c|c|c|c|}
\hline Month & Variables & Additives & Level & Means & $-95 \%$ & $+95 \%$ & $\mathrm{P}$ \\
\hline \multirow[t]{2}{*}{0} & $\% \mathrm{CY}$ & PPP & 1 & 85,4 & 82,9 & 88,0 & 0,0323 \\
\hline & & & 5 & 89,8 & 87,1 & 92,4 & \\
\hline \multirow[t]{2}{*}{0} & $\% \mathrm{MC}$ & TR & 0 & 71,7 & 70,9 & 72,4 & 0,0262 \\
\hline & & & 3 & 70,3 & 69,5 & 71,0 & \\
\hline \multirow[t]{2}{*}{1} & $\% \mathrm{CY}$ & $\mathrm{pH}$ & 9 & 86,4 & 84,7 & 88,1 & 0,0313 \\
\hline & & & 11 & 87,8 & 86,2 & 89,4 & \\
\hline \multirow[t]{2}{*}{1} & $\% \mathrm{CY}$ & PPP & 1 & 85,3 & 83,6 & 87,0 & 0,0100 \\
\hline & & & 5 & 88,7 & 87,1 & 90,4 & \\
\hline \multirow[t]{2}{*}{1} & $\% \mathrm{CY}$ & PI & 1 & 85,9 & 84,3 & 87,5 & 0,0117 \\
\hline & & & 5 & 88,7 & 87,0 & 90,4 & \\
\hline \multirow[t]{2}{*}{1} & $\% \mathrm{MC}$ & PPP & 1 & 69,9 & 69,4 & 70,5 & 0,0088 \\
\hline & & & 5 & 70,9 & 70,4 & 71,4 & \\
\hline \multirow[t]{2}{*}{1} & $\% \mathrm{MC}$ & $\mathrm{TR}$ & 0 & 71,0 & 70,5 & 71,5 & 0,0034 \\
\hline & & & 3 & 69,9 & 69,3 & 70,4 & \\
\hline \multirow[t]{2}{*}{1} & Springiness & TR & 0 & 1,06 & 0,72 & 1,39 & 0,0082 \\
\hline & & & 3 & 1,62 & 1,27 & 1,97 & \\
\hline \multirow[t]{2}{*}{1} & Springiness & PI & 1 & 1,45 & 1,11 & 1,79 & 0,0444 \\
\hline & & & 5 & 1,15 & 0,80 & 1,50 & \\
\hline \multirow[t]{2}{*}{1} & Cohesiveness & PI & 1 & 0,54 & 0,46 & 0,62 & 0,0334 \\
\hline & & & 5 & 0,44 & 0,36 & 0,52 & \\
\hline \multirow[t]{2}{*}{2} & $\% \mathrm{CY}$ & PPP & 1 & 81,0 & 79,1 & 82,9 & 0,0235 \\
\hline & & & 5 & 84,4 & 82,5 & 86,2 & \\
\hline
\end{tabular}

Additives did not exert any significant effect on the parameters water holding capacity, soluble protein, hardness, gumminess and chewiness. Also, no particular effect resulted for all attributes during the third and the fourth freezing month. Increasing protein content several textural characteristics, such as hardness, chewiness and cohesiveness are also increased (Hayes et al., 2005; Hughes et al., 1997). However, in the present study the addition of PPP and PI to fresh minced beef samples did not have a significant effect on these attributes compared to the STP sample, but only when compared to the blank one. This can be partially explained by the fact that the addition of these proteins took place at high $\mathrm{pH}$ values (9 or 11), where they have increased solubility. When the proteins are introduced back to the minced beef, they partially refold. This new conformation of the proteins has been shown in other studies to exhibit good functional properties, including solubility and emulsification (Hultin \& Kelleher, 1999; Undeland et al., 2002; Kristinnson \& Hultin, 2003; Liang \& Hultin, 2003). The fact that no significant difference was observed in the $\mathrm{pH}$ of the cooked minced samples and additionally that $\mathrm{pH}$ was in all samples well above the isoelectric point of the major proteins in meat $\mathrm{pH}$ 5-5.5) can explain why water holding capacity showed no marked differences (Gault, 1984).

\subsection{Principal Component Analysis}

Principal Component Analysis (PCA) on both variables and additive factors, the latter treated as dummy variables, resulted in the formation of two major axes explaining $46.5 \%$ of the total variation. The first axis is composed mostly by the variables hardness (HARD), cook yield (CY), moisture content (MC) and freezing months 0 and 2 (Freeze_0 and Freeze_2) due to their high correlation values with this axis (Table 4, Figure 1). The second axis is formed by high correlation values of springiness, cohesiveness and secondarily by $\mathrm{pH}$ and trehalose 3\% (TR_3). 
Table 4. Correlation coefficients between PCA axes 1 and 2 and variables (additive factors are shown as dummy variables). The two axes explain $46.5 \%$ of the total variation.c

\begin{tabular}{lll}
\hline Variable & Axis 1 & Axis 2 \\
\hline HARD & 0,937 & $-0,083$ \\
Freeze_2 & $-0,814$ & $-0,037$ \\
CY & 0,791 & 0,168 \\
Freeze_0 & 0,767 & 0,052 \\
MC & 0,734 & 0,343 \\
PPP_5 & 0,411 & $-0,336$ \\
PI_1 & $-0,148$ & 0,103 \\
SPRING & 0,081 & $-0,785$ \\
COHES & $-0,241$ & $-0,642$ \\
WHC & 0,553 & $-0,567$ \\
pH_11 & 0,011 & 0,493 \\
TR_3 & $-0,122$ & $-0,426$ \\
\%SolPro & $-0,209$ & 0,280 \\
Variance & 3,912 & 2,133 \\
Variance \% & 30,1 & 16,4 \\
\hline
\end{tabular}

According to the findings of Figure 1, moisture, cook yield and hardness show positive strong correlation with the time soon as the samples had been cooked (month 0 ) and negative strong correlation after freezing for two months, indicating the strong negative effect of freezing at $-20^{\circ} \mathrm{C}$ for two months. This is also in agreement with the data on Figure 2, where it can be observed that after 2 months of freezing the cook yield, and textural characteristics of PPP and PI are rapidly deteriorating. Freezing, and especially at slow rate $\left(-20^{\circ} \mathrm{C}\right)$ can have adverse effects on meat textural characteristics, cook yield and WHC. Most of these effects are attributed to protein denaturation. When meat is frozen at a slow rate or warmer temperatures, there is considerably more damage done to the fibres and myofibrils (Petrovic et al., 1993). PPP and PI, individually, at levels 5\% were able to maintain a high cooking yield of the minced samples compared to the blank for all four months of frozen storage. However, cohesiveness (COHES) and hardness (HARD) were not maintained at high values after 1 month of storage. Springiness and cohesiveness correlate strongly and positively in the addition of $3 \%$ trehalose but strongly negatively when the added solution was adjusted to $\mathrm{pH} 11$. A possible explanation for this is that trehalose solutions resist degradation between $\mathrm{pH} 3.5$ and 10 (Teramoto et al., 2008). A higher pH, such as 11 that was used in the added solution containing trehalose could alter trehalose structure and therefore alter its functionality. A loose positive correlation occurs between water holding capacity (WHC) and 5\% addition of porcine plasma protein. 


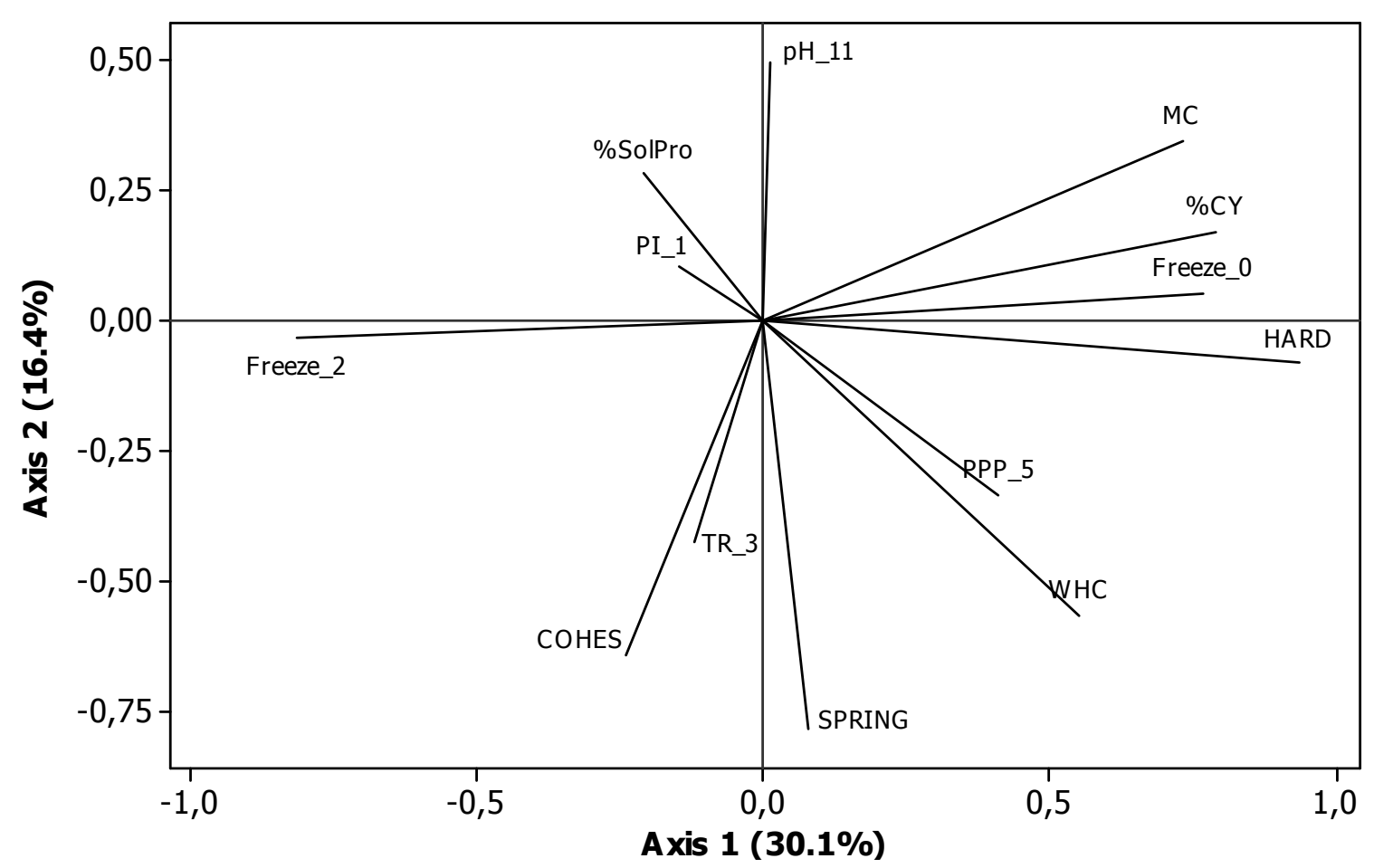

Figure 1. Correlation biplot of physicochemical, mechanical and dummy additive variables by the principal component analysis

\subsection{Comparison With Sodium Polyphosphate}

Statistical analysis showed that the two additives that had a significant positive effect on cook yield and on some of the textural parameters were PPP and PI. The additives' effects were compared to those produced by polyphosphates and blank material by freezing month. Freezing time affects drastically the shift of some of the attributes when additives such PPP and PI are present in the minced meat (Figures 2 and 3). Cook yield, at PPP addition, remains steady until the first month of freezing declining thereafter and reaching the lowest values in the fourth month (Figure 2). A comparable shift is obvious for the blank +STP sample. On the other hand the absence of PPP or STP from the mince (blank sample) results in an abrupt drop of the cook yield after freezing for one month which afterwards remains more or less steady by time. The same pattern is observed for PI addition as well (Figure 3). 




Interval Plot of HARDNESS

$95 \%$ CI for the Mean

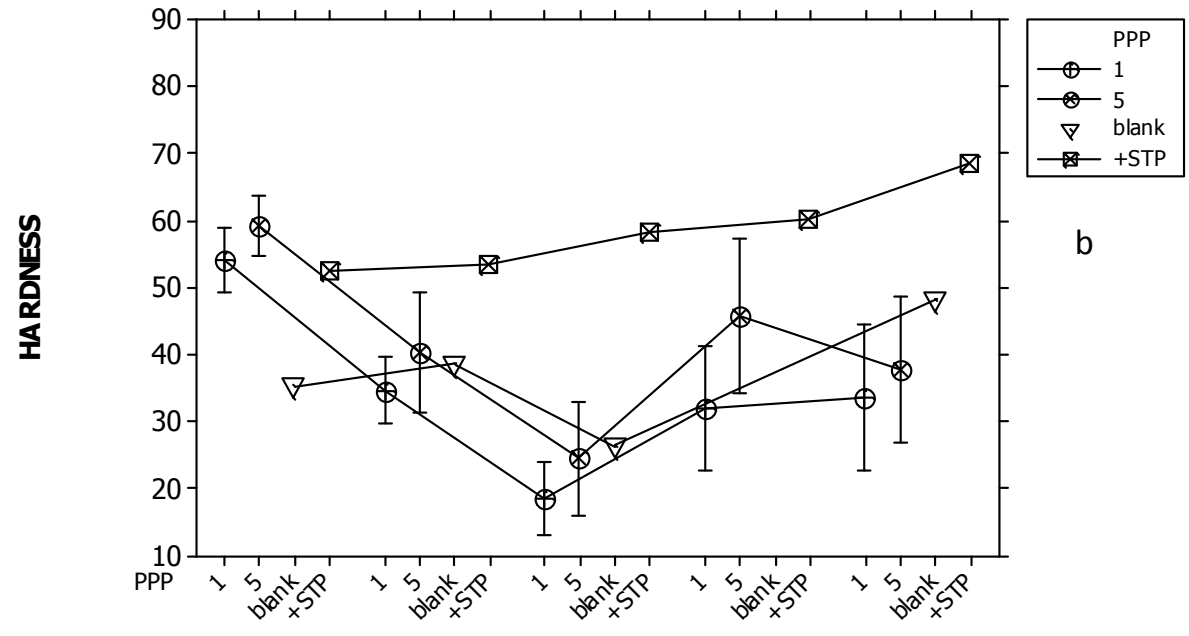

FreezeTime

0

Interval Plot of COHESIVENESS

$95 \%$ CI for the Mean



Figure 2. Monthly mean changes of (a) cook yield, (b) hardness and (c) cohesiveness at two PPP addition levels, without additives (blank) and with addition of polyphosphates (+STP). Vertical lines denote the $95 \%$ confidence intervals of the means 


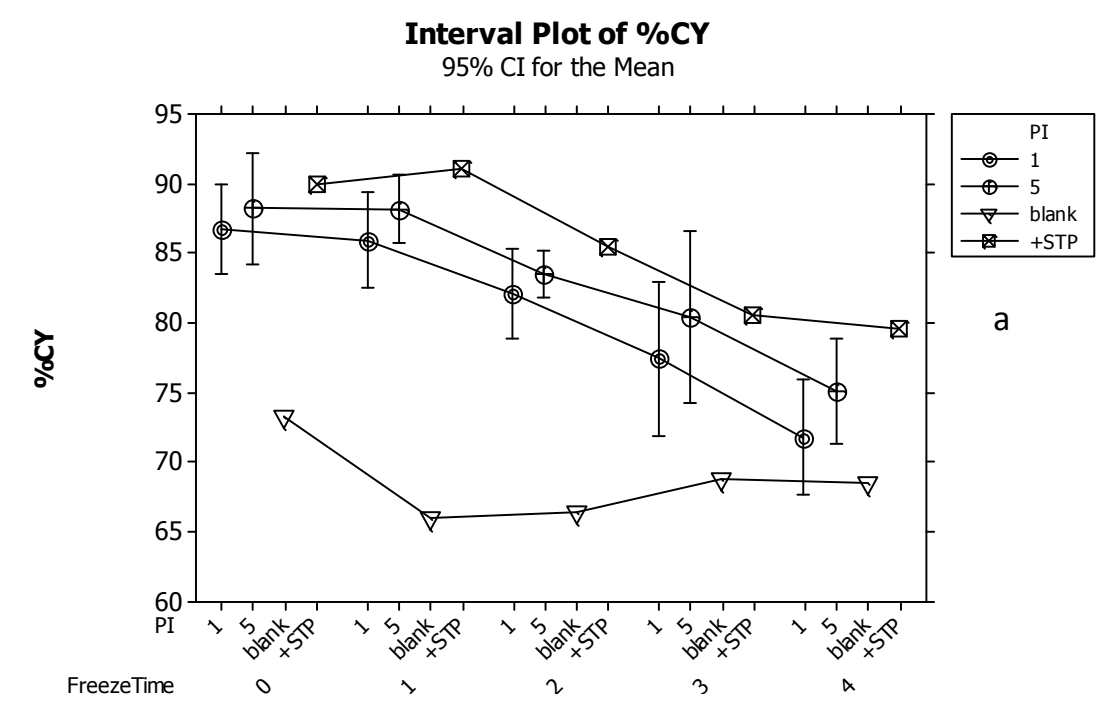

\section{Interval Plot of HARDNESS}

95\% CI for the Mean

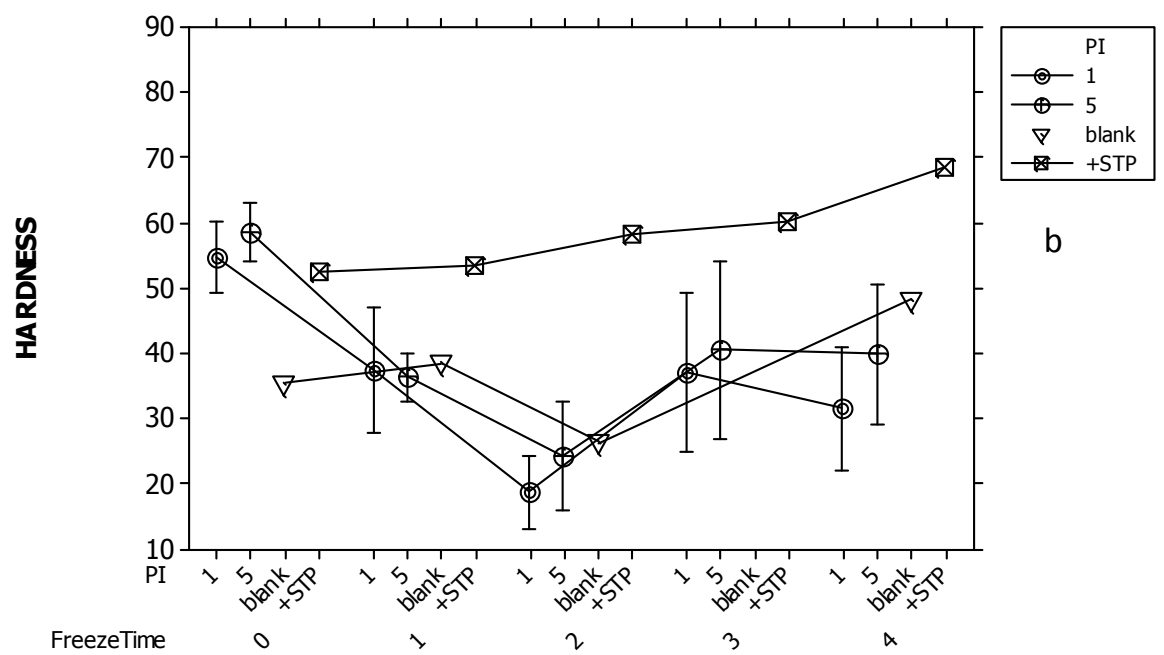

Interval Plot of COHESIVENESS

95\% CI for the Mean



Figure 3. Monthly mean changes of (a) cook yield, (b) hardness and (c) cohesiveness at two PI addition levels, without additives (blank) and with addition of polyphosphates (+STP). Vertical lines denote the $95 \%$ confidence intervals of the means 
At PPP addition, the mechanical hardness decreases with time approaching a minimum in the second month and then stabilizes in a position a bit upwards in the following two months (Figure 2). Blank sample follows a same direction. The addition of STP though results in a steady, slightly gradual increase in hardness. At PI addition, a similar pattern takes place (Figure 3).

Mechanical cohesiveness remains steady without undulations by freezing time for both additives present, as the blank sample does too. However the shift of cohesiveness for the STP sample increases markedly with time approximating higher values than those of additives (Figures 2 and 3).

Conclusively, it can be said that both PPP and PI individually, and especially at the 5\% level of addition, can increase cook yield of fresh and frozen minced beef to the same extent as the polyphosphates do. On the other hand, the effect of PPP and PI on mechanical hardness is similar to polyphosphates only for the fresh samples $(0$ freeze time), while they exert no effect on cohesiveness.

\subsection{Optimization}

Optimization procedure was based on those variables that were mostly influenced by the factors under study (see ANOVA results, Table 3).

Thus, by setting the chemical variables, cook yield and moisture content; at ranges near their optimal performance, that is their maximal, the overlaid contour plots as affected by PI and PPP were obtained while holding the $\mathrm{pH}$ and trehalose levels at 11 and 3\% respectively (Figure 4). The white region of the plot is the feasible region, or the area that satisfies the criteria for all responses. The optimal chemical conditions were achieved at PI concentration 2.3-5.0\% and PPP levels 1.7-4.7\% which both define performance of $90 \%$ cook yield and $71.6 \% \mathrm{MC}$.



Figure 4. Overlaid contour plot of cook yield and moisture content at varying levels of PI and PPP concentration

Regarding the mechanical springiness, its optimal performance is obtained in the area defined by the narrow stripe shown in Figure 5 that corresponds to springiness $1.65-1.75$, PI 3-3.7\% and TR 1.5-1.9\% while holding pH and PPP at midrange levels 10 and $3 \%$. 


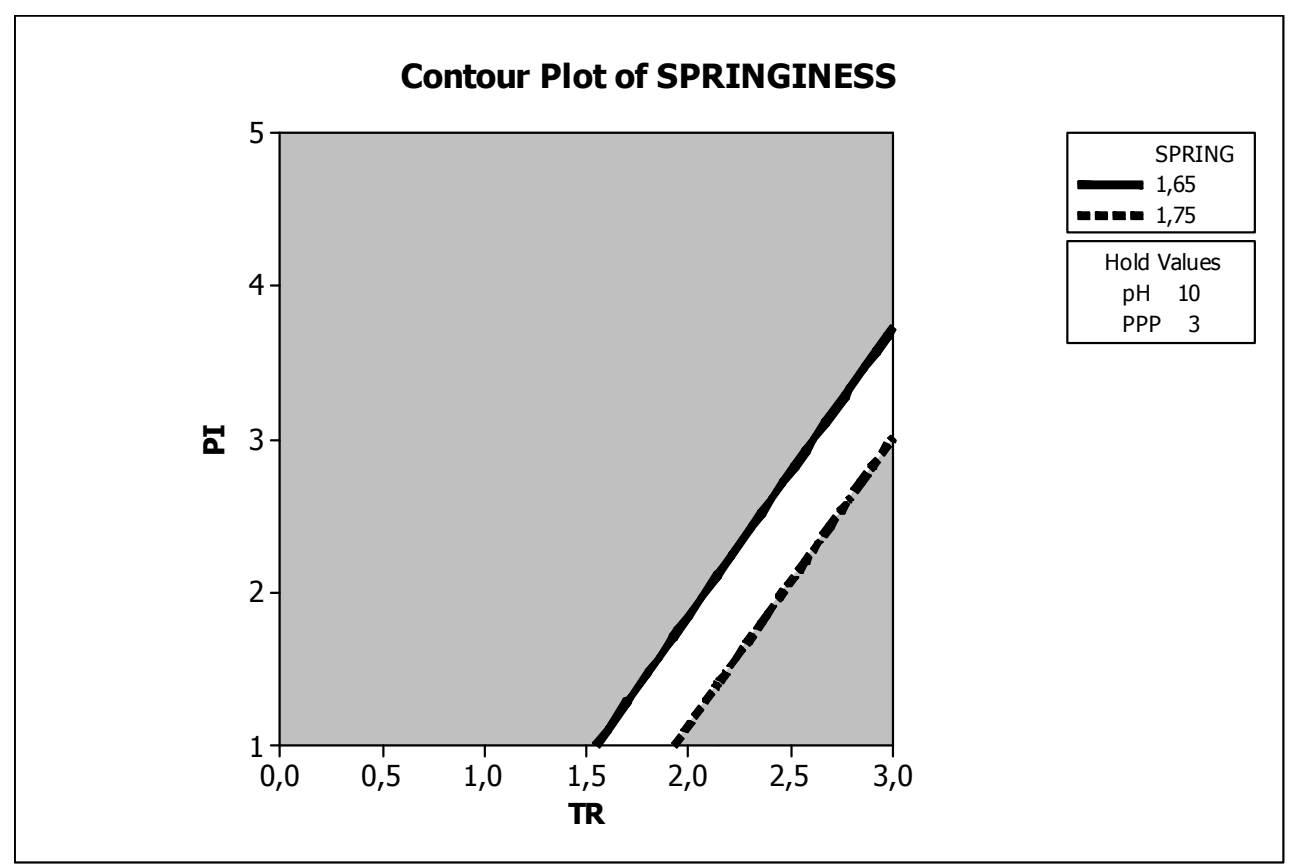

Figure 5. Overlaid contour plot of springiness at varying levels of PI and TR concentration

\section{Conclusions}

PCA reveals two bundles of variables with a distinguishing but uniform behaviour: moisture content, cook yield and mechanical hardness start their maxima before freezing commences (freezing time 0 , first bundle) and mechanical springiness and cohesiveness show high values at 3\% trehalose addition which occurs one month after freezing (second bundle). Trehalose did not enhance cook yield of fresh or frozen minced beef samples. Porcine plasma protein and protein isolate from bovine meat were able to increase cook yield of beef samples to a similar extend as the STP did. PPP and PI did not alter colour or the pH of the samples compared to STP, nor affected textural parameters especially for the fresh samples and for the samples that were frozen for one month. Therefore, PPP and PI can be used as a polyphosphate alternative in the meat industry.

\section{References}

Abdullah, B., \& Al-Najdawi, R. (2005). Functional and sensory properties of chicken meat from spent-hen carcasses deboned manually or mechanically in Jordan. International Journal of Food Science and Technology, 40, 537-543. http://dx.doi.org/10.1111/j.1365-2621.2005.00969.x

Alting, A. C., Jongh, H. H. J., Visschers, R. W., \& Simons, J. W. F. A. (2002). Physical and chemical interactions in cold gelation of food proteins. Journal of Agricultural and Food Chemistry, 50(16), 4682-4689. http://dx.doi.org/10.1021/jf011657m

Amann, K., Törnig, J., Kugel, B., Gross, M. L., Tyralla, K., \& El-Shakmak, A. (2003). Hyperphosphatemia aggravates cardiac fibrosis and microvascular disease in experimental uremia. Kidney International, 63, 1296-1301. http://dx.doi.org/10.1046/j.1523-1755.2003.00864.x

AOAC. (1990). Official methods of analysis (15th ed.). Washington, DC: Assoc. of Official Analytical Chemists.

Atughonu, A. G., Zayas, J. F., Herald, T. J., \& Harbers, L. H. (1998). Thermo-rheology, quality characteristics, and microstructure of frankfurters prepared with selected plant and milk additives. Journal of Food Quality, 21, 223-238. http://dx.doi.org/10.1111/j.1745-4557.1998.tb00518.x

Benjakul, S., Visessanguan, W., \& Srivilai, C. (2001). Porcine plasma proteins as gel enhancer in bigeye snapper (piuacanthus tayenus) surimi. Journal of Food Biochemistry, 25, 285-305. http://dx.doi.org/10.1111/j.1745-4514.2001.tb00741.x

Cheftel, J. C., Cuq, J., \& Lorient, D. (1985). Amino acids, peptides and proteins. In O. Fennema (Ed.), Food Chemistry (pp. 245-370). New York, NY: Marcel Dekker, Inc.

Chen, M. J., \& Lin, C. W. (2002). Factors Affecting the Water-Holding Capacity of fibrinogen/Plasma Protein 
Gels Optimized by Response Surface Methodology. Journal of Food Science, 67, 2579-2582. http://dx.doi.org/10.1111/j.1365-2621.2002.tb08780.x

Cofrades, S., Guerra, M. A., Carballo, J., Fernández-Martín, F., \& Jiménez-Colmenero, F. (2000). Plasma protein and soy fiber content effect on bologna sausage properties as influenced by fat level. Journal of Food Science, 65(2), 281-287. http://dx.doi.org/10.1111/j.1365-2621.2000.tb15994.x

Colaco, C. A. L. S., Smith, C. J. S., Sen, S., Roser, D. H., Newman, Y., Ring, S., \& Roser, B.J. (1994). Chemistry of protein stabilization by trehalose. Formulation and Delivery of Proteins and Peptides, 567, 222-240. http://dx.doi.org/10.1021/bk-1994-0567.ch014

Dàvila, E., Parés, D., Cuvelier, G., \& Relkin, P. (2007). Heat-induced gelation of porcine blood plasma proteins as affected by pH. Meat Science, 76, 216-225. http://dx.doi.org/10.1016/j.meatsci.2006.11.002

Dreeling, N., Allen, P., \& Butler, F. (2000). Effect of cooking method on sensory and intrumental texture attributes of low-fat beefburgers. Lebensmittel Wissenschaft Technologie, 33, 234-238.

Erdogdu, S. B., Erdogdu, F., \& Ekiz, H. I. (2007). Influence of sodium tripolyphosphate (STP) treatment and cooking time on cook losses and textural properties of red meats. Journal of Food Process Engineering, 30, 685-700. http://dx.doi.org/10.1111/j.1745-4530.2007.00139.x

Farouk, M. M., Wieliczko, K., Lim, R., Turnwald, S., \& MacDonaldb, G. A. (2001). Cooked sausage batter cohesiveness as affected by sarcoplasmic proteins. Meat Science, 61, 85-90. http://dx.doi.org/10.1016/S0309-1740(01)00168-1

Feiner, G. (2006). Meat products handbook. Practical science and technology. Cambridge: CRC Press and Woodhead Publishing Limited. http://dx.doi.org/10.1533/9781845691721

Fenton, T., Lyon, A., Eliasziw, M., Tough, S., \& Hanley, D. (2009). Phosphate decreases urine calcium and increases calcium balance: A metaanalysis of the osteoporosis acid-ash diet hypothesis. Nutrution. Journal, 8, 41. http://dx.doi.org/10.1186/1475-2891-8-41

Foley, R. N., Collins, A. J., Herzog, C. A., Ishani, A., \& Kalra, P. A. (2009). Serum phosphorus levels associate with coronary atherosclerosis in young adults. Journal of the American Society of Nephrology, 20(2), 397-404. http://dx.doi.org/10.1681/ASN.2008020141

Gault, N. F. S. (1985). The Relationship Between Water-Holding Capacity and Cooked Meat Tenderness in Some Beef Muscles as Influenced by Acidic Conditions Below the Ultimate pH. Meat Science, 15, 15-30. http://dx.doi.org/10.1016/0309-1740(85)90071-3

Gornall, A. J., Bardawill, C. J., \& David, M. M. (1949). Journal of Biological Chemistry, 177(2), 751-766.

Hayes, J. E., Desmond, E. M., Troy, D. J., Buckley, D. J., \& Mehra, R. (2005). The effect of whey protein-enriched fractions on the physical and sensory properties of frankfurters. Meat Science, 71, 238-243. http://dx.doi.org/10.1016/j.meatsci.2005.03.005

Howell, N. K., \& Lawrie, R. A. (1984). Functional aspects of blood plasma proteins, Gelling properties. Journal of Food Technology, 19, 289-295. http://dx.doi.org/10.1111/j.1365-2621.1984.tb00352.x

Hughes, E., Cofrades, S., \& Troy, D. J. (1997). Effects of fat level, oat fibre and carrageenan on frankfurters formulated with $5, \quad 12$ and $30 \%$ fat. Meat Science, 45(3), 273-281. http://dx.doi.org/10.1016/S0309-1740(96)00109-X

Hultin, H. O., \& Kelleher, S. D. U. S. (1999). Protein composition isolated from a muscle source-US6005073A. Retrieve from http://global.soopat.com/Patent/Patent/US6005073A

Hurtado, S., Saguer, E., Toldrà, M., Dolors Parés, D., \& Carmen Carretero, C. (2012). Porcine plasma as polyphosphate and caseinate replacer in frankfurters. Meat Science, 90, 624-628. http://dx.doi.org/10.1016/j.meatsci.2011.10.004

Huttunen, M. M., Pietilä, P. E., Viljakainen. H. T., \& Lamberg-Allardt, C. J. E. (2006). Prolonged increase in dietary phosphate intake alters bone mineralization in adult male rats. Journal of Nutrion and Biochemestry, 17, 479-484. http://dx.doi.org/10.1016/j.jnutbio.2005.09.001

Jain, N. K., \& Ipsita Roy, I. (2009). Effect of trehalose on protein structure. Protein Science, 18, 24-36.

Kim, G.-D., \& Jung, T.-C. (2013). Optimization of processing conditions for meat paper from beef semimembranosus muscle using response surface methodology. LWT - Food Science and Technology, 50(1), 326-330. 
Kovačević, D., \& Mastanj ević, K. (2011). Cryoprotective effect of trehalose and maltose on washedand frozen stored beef meat. Czech Journal of Food Science, 29, 15-23.

Kristinsson, H. G., \& Hultin, H. O. (2003). Effect of low and high pH treatment on the functional properties of cod muscle proteins. Journal of Agricultural and Food Chemistry, 51(17), 5103-5110. http://dx.doi.org/10.1021/jf026138d

Lampila, L. E. (1992). Functions and uses of phosphates in the seafood industry. Journal of Aquatic Food Product Technology, 1, 29-41. http://dx.doi.org/10.1300/J030v01n03_04

Liang, Y., \& Hultin, H. O. (2003). Functional protein isolates from mechanically deboned turkey by alkaline solubilization with isoelectric precipitation. Journal of Muscle Foods, 14, 195-205. http://dx.doi.org/10.1111/j.1745-4573.2003.tb00700.x

MacDonald, G. A., \& Lanier, T. (1991). Carbohydrates as cryoprotectants for meats and surimi. Food Technology, 45, 150-159.

Martin, F. F., Cofrades, S., Carballo, J., \& Jimenezcolmenero, F. (2002). Salt and phosphate effects on the gelling process of pressure/heat treated pork batters. Meat Science., 61, 15-23. http://dx.doi.org/10.1016/S0309-1740(01)00157-7

Montgomery, C. D. (2001). Design and analysis of experiments (pp. 303-350). John Wiley and Sons, Inc.

Murphy, S. C., \& Gilroy, D. (2004). Evaluation of surimi, fat and water content in a low/no added pork sausage formulation using response surface methodology. Meat Science, 66, 689-701. http://dx.doi.org/10.1016/j.meatsci.2003.07.001

Naozumi T. N., Sachinvala, N. D., \& Shibata, M. (2008). Trehalose and trehalose-based polymers for environmentally benign, biocompatible and bioactive materials. Molecules, 13, 1773-1816. http://dx.doi.org/10.3390/molecules13081773

Nolsoe, H., \& Undeland, I. (2009). The acid and alkaline solubilization process for the isolation of muscle proteins: State of the art. Food Biotechnology, 2, 1-27.

Parés, D., \& Ledward, D. A. (2001). Emulsifying and gelling properties of porcine blood plasma as influenced by high-pressure processing. Food Chemistry, 74(2), 139-145. http://dx.doi.org/10.1016/S0308-8146(01)00105-4

Park, J. W., Lanier, T. C., \& Green, D. P. (1988). Cryoprotective effects of sugar, polyols, and or phosphates on Alaska pollack surimi. Journal of Food Science, 53, 1-3. http://dx.doi.org/10.1111/j.1365-2621.1988.tb10163.x

Patist, A., \& Zoerb, H. (2005). Preservation mechanisms of trehalose in food and biosystems. Colloids and Surfaces B: Biointerfaces, 40, 107-113. http://dx.doi.org/10.1016/j.colsurfb.2004.05.003

Pereira, A. G. T., \& Ramos, E. M. (2011). Effects of the addition of mechanically deboned poultry meat and collagen fibers on quality characteristics of frankfurter-type sausages. Meat Science, 89(4), 519-525. http://dx.doi.org/10.1016/j.meatsci.2011.05.022

Petridis, D., Ritzoulis, C., Tzivanos, I., Vlazakis, E., Derlikis, E., \& Vareltzis, P. (2013). Effect of fat volume fraction, sodium caseinate, and starch on the optimization of the sensory properties of frankfurter sausages. Food Science \& Nutrition, 1, 32-44. http://dx.doi.org/10.1002/fsn3.6

Petrovic, L., Grujic, R., \& Petrovic, M. (1993). Definition of the optimal freezing rate-2. Investigation of the physico-chemical properties of beef $\mathrm{m}$. longissimus dorsi frozen at different freezing rates. Meat Science, 33, 319-331. http://dx.doi.org/10.1016/0309-1740(93)90004-2

Rincón, F., \& Martínez, B. (2008). The roles of pH extraction and colloidal protein solubility in the optimization of spectrophotometric nitrite determination in meat products via response surface methodology. Meat Science, 80(3), 744-752. http://dx.doi.org/10.1016/j.meatsci.2008.03.016

Ritzoulis, C., Petridis, D., Derlikis, E. M., Fytianos, K., \& Asteriou, P. (2010). Utilization of inverse water-in-oil emulsions as fat replacers in frankfurter model sausages: influence of fat-emulsion content on the organoleptic and mechanical properties. Journal of Texture Studies, 41, 62-74. http://dx.doi.org/10.1111/j.1745-4603.2009.00213.x

Sherman, R. A., \& Mehta, O. (2009). Dietary phosphorus restriction in dialysis patients: Potential impact of processed meat, poultry, and fish products as protein sources. American Journal of Kidney Diseases, 54(1), 
18-23. http://dx.doi.org/10.1053/j.ajkd.2009.01.269

Sola-Penn, M., \& Meyer-Fernandes, J. R. (1998). Stabilization against thermal inactivation promoted by sugars on enzyme structure and function: why is trehalose more effective than other sugars? Archives of Biochemestry \& Biophysics, 360, 10-14. http://dx.doi.org/10.1006/abbi.1998.0906

Tahergorabi, R., \& Beamer, S. K. (2011). Effect of isoelectric solubilization/precipitation and titanium dioxide on whitening and texture of proteins recovered from dark chicken-meat processing by-products. LWT-Food Science and Technology, 44(4), 896-903.

Tahergorabi, R., \& Sivanandan, L. (2012a). Dynamic rheology and endothermic transitions of proteins recovered from chicken-meat processing by-products using isoelectric solubilization/precipitation and addition of TiO2. LWT-Food Science and Technology, 46(1), 148-155.

Tahergorabi, R., \& Beamer, S. K. (2012b). Functional food products made from fish protein isolate recovered with isoelectric solubilization/precipitation. LWT-Food Science and Technology, 48(1), 89-95.

Unal, S. B., Erdogdu, F., \& Ekiz, H. I. (2006). Effect of temperature on phosphate diffusion in meats. Journal of Food Engineering, 76, 119-127. http://dx.doi.org/10.1016/j.jfoodeng.2005.04.041

Undeland, I., Kelleher, S. D., \& Hultin, H. O. (2002). Recovery of functional proteins from herring (Clupea harengus) light muscle by an acid or alkaline solubilization process. Journal of Agricultural and Food Chemistry, 50, 7371-7379. http://dx.doi.org/10.1021/jf020199u

Vareltzis, P., \& Undeland, I. (2008). Removal of lipids and diarrhetic shellfish poisoning toxins from blue mussels (Mytilus edulis) during acid and alkaline isolation of proteins. Journal of Agricultural and Food Chemistry, 56, 3675-81. http://dx.doi.org/10.1021/jf800224n

Vittadini, E., Rinaldi, M., Chiavaro, E., Barbanti, D., \& Massini, R. (2005). The effect of different convection cooking methods on the instrumental quality and yield of pork Longissimus dorsi. Meat Science, 69, 749-756. http://dx.doi.org/10.1016/j.meatsci.2004.11.005

Whybro, A., Jagger, H. Barker, M., \& Eastell, R. (1998). Phosphate supplementation in young men: lack of effect on calcium homeostasis and bone turnover. European Journal of Clinical Nutrition, 52, 29-33. http://dx.doi.org/10.1038/sj.ejcn.1600508

Zayas, J. F. (1985). Structural and water binding properties of meat emulsions prepared with emulsified and $\begin{array}{lllll}\text { unemulsified fat. Journal of Food } & \text { Science, } & 50(3), & \text { 6892. }\end{array}$ http://dx.doi.org/10.1111/j.1365-2621.1985.tb13773.x

\section{Copyrights}

Copyright for this article is retained by the author(s), with first publication rights granted to the journal.

This is an open-access article distributed under the terms and conditions of the Creative Commons Attribution license (http://creativecommons.org/licenses/by/3.0/). 